\title{
Effect of Acetic Acid on Bacteriocin Production by Gram-Positive Bacteria
}

\author{
Jingping $\mathrm{Ge}^{1,2}$, Jie Kang ${ }^{1,2}$, and Wenxiang Ping ${ }^{1,2 *}$ \\ ${ }^{1}$ Engineering Research Center of Agricultural Microbiology Technology, Ministry of Education, Heilongjiang University, Harbin 150500, \\ P.R. China \\ ${ }^{2}$ Key Laboratory of Microbiology, College of Heilongjiang Province, School of Life Sciences, Heilongjiang University, Harbin 150080, P.R. China
}

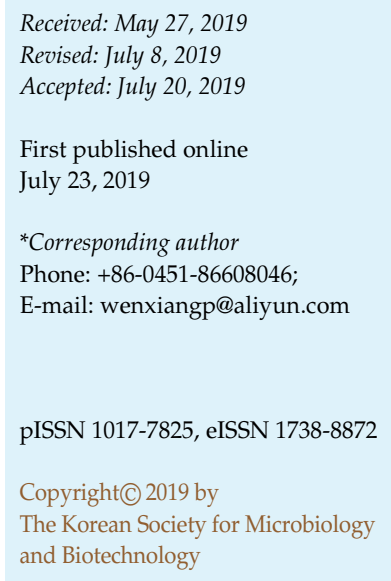

Acetic acid is indirectly involved in cell center metabolism, and acetic acid metabolism is the core of central metabolism, affecting and regulating the production of bacteriocin. Bacteriocin is a natural food preservative that has been used in the meat and dairy industries and winemaking. In this paper, the effects of acetic acid on bacteriocin produced by Gram-positive bacteria were reviewed. It was found that acetic acid in the undissociated state can diffuse freely through the hydrophobic layer of the membrane and dissociate, affecting the production, yield, and activity of bacteriocin. In particular, the effect of acetic acid on cell membranes is summarized. The link between acetic acid metabolism, quorum sensing, and bacteriocin production mechanisms is also highlighted.

Keywords: Bacteriocin, acetic acid, gram-positive bacteria, acetic acid metabolism, signal molecule

\section{Introduction}

Bacteriocin is a small molecule polypeptide with antiseptic and anticancer properties synthesized by ribosomes. Therefore, bacteriocin has good performance in inhibiting the growth of a variety of pathogenic microorganisms and food spoilage bacteria. In the past decade or so, articles on the application of bacteriocins in biomedical fields accounted for most of those published [1], with the majority of these related to the study of bacteriocins produced by Gram-negative bacteria. Bacteriocin research on Gram-positive bacteria is still in its infancy and is mainly concentrated on lactic acid bacteria. It is worth noting that the production of bacteriocin is accompanied by the production of acetic acid [2], indicating that there must be some connection between the metabolism of acetic acid and the production of bacteriocin.

Acetic acid metabolism refers to the cycle and transformation between acetic acid and acetyl-CoA [3], which is ubiquitous in bacterial cells. Many intermediates of acetic acid metabolism such as acetyl-CoA contain both acetyl groups and phosphate groups and are the basis for intracellular material circulation and energy flow. So, acetic acid metabolism is the core link in central metabolism [4] and is closely related to bacterial physiological activities. Bacteriocins can be used as colonizing peptides, antimicrobial or killing peptides and signaling peptides to regulate the ecological function of microorganisms [5]. As agents of anti-competitors, bacteriocins will invade a new community [6]. After successfully establishing its own community, bacteriocin prevents invasion by other species, and regulates population dynamics by regulating intercellular competition [5]. Co-culture induction [7] and the addition of cell-free supernatants [8] increase bacteriocin production. This result validates the ecological function of bacteriocin. Acetic acid metabolism regulates physiological activities in cells, and bacteriocin regulates extracellular physiological activities. The most important thing is that the two are inseparable. In Gram-positive bacteria, many biological traits are regulated by the metabolism of acetic acid such as entering competence [9], biofilm formation [10], bacteriocin production [7], and exhibition of virulence [11]. Bacteria indirectly regulate the production and ecological function of bacteriocins by acetic acid metabolism. This paper 
discusses the effects of acetic acid on bacteriocin production by Gram-positive bacteria. It also illustrates the relationship between quorum sensing and acetic acid metabolism, and the impact of the microenvironment on bacteriocin production.

\section{Effects of Acetic Acid on Bacteriocin Production and Activity at Physiological Metabolic Levels}

\section{Effects of $\mathrm{pH}$ and Acetic Acid Dissociation on the Yield and Activity of Bacteriocin}

The classification of bacteriocins is complex and controversial. This article summarizes the classification of bacteriocins according to the ideas of Mr. Eldin Maliyakkal Johnson (Table 1) [12]. Bacteriocin is a metabolite of polypeptide produced by bacteria and has a certain bactericidal effect. The effect of acetic acid on the production and bioactivity of bacteriocin is divided into two aspects. On the one hand, the $\mathrm{pH}$ affects the production and bioactivity of bacteriocin. Bacteriocin is produced in a specific $\mathrm{pH}$ range, and bacteriocin production is significantly correlated with initial $\mathrm{pH}$ [13]. However, the final production $\mathrm{pH}$ is almost the same or lower [14]. The literature indicates that bacteriocin is not produced when the final production $\mathrm{pH}$ is less than 4.5 [15], and the optimal $\mathrm{pH}$ range for production is $6.0-6.5[15,16]$. The bioactivity of bacteriocin has a broad $\mathrm{pH}$ range (Table 1 ) [17], with some bacteriocins remaining active in acidic and alkaline environments, however, the optimal $\mathrm{pH}$ range for their bioactivity is 5-7. Extreme $\mathrm{pH}$ will significantly reduce bacteriocin activity [18] because a strong acid or strong alkali environment can affect the spatial structure of

Table 1. Classification and characteristics of bacteriocins.

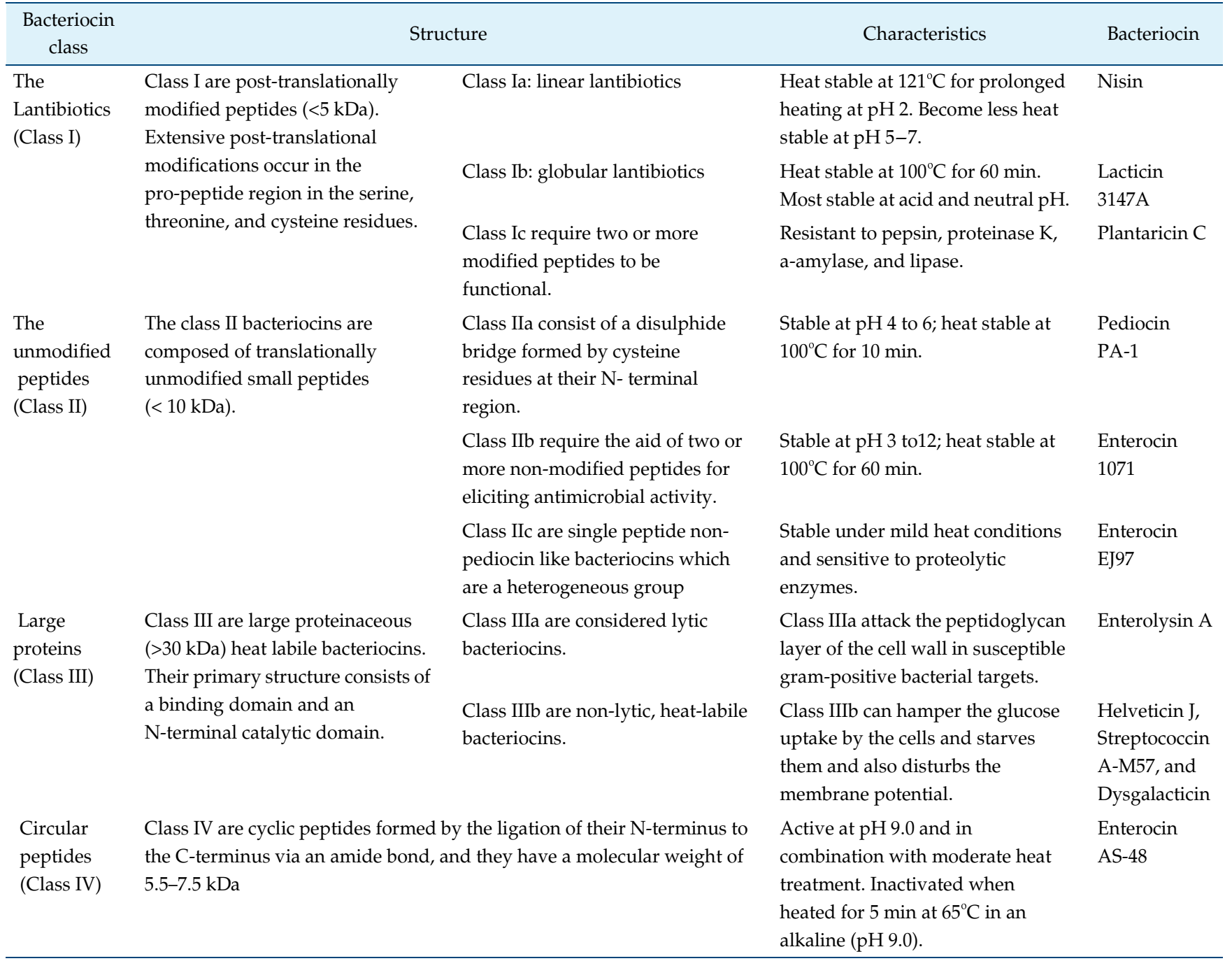


the protein. Moreover, extreme $\mathrm{pH}$ can also destroy the signal molecule structure of bacteriocin, causing a partial loss of function and hindering communication between bacteria. In summary, the production of bacteriocin may be related to both the initial and active $\mathrm{pH}$ during bacteriocin production, indicating that $\mathrm{pH}$ acts as an important signaling system.

On the other hand, acetic acid as an organic acid, whether it is in a dissociated state affects the production of bacteriocin. When the $\mathrm{pH}$ is equal to $\mathrm{pKa}$ (acidity coefficient), acetic acid hardly ionizes and can freely diffuse through the cell membrane. When the intracellular $\mathrm{pH}$ is high, acetic acid can decompose to release protons and conjugate bases. Acetate is considered to be an inducer of bacteriocin production [19]. A large number of hydrogen ions can destroy the membrane proton kinetics [20], affecting the secretion of bacteriocin. At the same time, the release of protons acidifies the cytoplasm [21]. Acid shock may affect the activity of the electron transport chain and disrupt cell metabolism [22, 23]. In the bacteria, resistance to stress is mainly maintained to ensure intracellular balance [24]. For example, Bacillus cereus reduces hydrogen ions in two ways: the first is to pump protons out of the cell, and the mature cell membrane and wall prevent protons from entering the cell. The second method relies on basic compounds, which can counteract the acidification of the cytoplasm, and the decarboxylation of amino acids depletes protons [25], such as glutamate [26], arginine and ornithine.

\section{Effects of Bacterial Cell Growth and Metabolism on} Bacteriocin Production under Acetic Acid Conditions

Bacteria can monitor themselves or competitors by signaling molecules. When a signal molecule reaches the concentration threshold, it can initiate the expression of related genes in the bacteria to maintain population stability. Quorum sensing behavior is a relatively common ecological phenomenon. Acetic acid can significantly activate the quorum sensing system, resulting in a decrease in bacterial growth rate. At this time, cell growth and metabolism are slowed down, protein synthesis is reduced, and succinic acid production is reduced [27]. Cells quickly adapt to changing environments by turning off unnecessary metabolism [28], preventing the misexpression of genes, conserving resources and purposefully expressing desired substances. This suggests that acetic acid affects the signaling pathways that control cell division and cellular nutrient diversity [29]. Acetic acid stimulation can also lead to cell growth arrest and even cell death [30]. The rupture of a single cell helps to increase the release of XIP, a sigma factor-inducing peptide [31], thereby increasing the resistance of the bacterial population and regulating the production of bacteriocin. In addition, high concentrations of acetate activate the metabolism of acetic acid, converting acetic acid to acetyl-coenzyme A [32]. The intermediates of acetic acid metabolism promote the activation and transmission of two-component system phosphorylation. In general, under acetic acid conditions, the population will eliminate individuals with poor competitiveness and establish an environmental condition that is not suitable for competitors.

\section{The Effect of Acetic Acid on Cell Membrane Promotes the Production of Bacteriocin}

The cell membrane is a semi-permeable membrane that blocks harmful substances from entering the cell and helps the bacteria to survive in adverse environments. Environmental signaling molecules and their threshold concentrations regulate the maturation of cell membranes [33], enhancing or attenuating the perception of a substance. Acetic acid can activate sensor proteins and transmit environmental signals to the cell membrane [34]. When Gram-positive bacteria are stimulated by acetic acid, the cell membrane of the bacteria changes [35]. On the one hand, the cell membrane reduces the permeability to acetic acid, and on the other hand, the maturation of the cell membrane promotes the production and secretion of bacteriocin.

Acetic acid regulates cell membrane maturation. The maturation of cell membranes is largely divided into four steps: surface attachment, microcolony formation, depth of mature cell membranes, and structure of mature cell membranes [36]. The early stage of cell membrane maturation is mainly regulated by acetic acid as a signaling molecule, and the late stage of cell membrane maturation is caused by acetic acid metabolism and quorum sensing. Acetic acid can modify the lipid membrane composition [37], for example, isomerizaton of cis-to trans-unsaturated fatty acids, increase of phosphatidylcholine, increase of cisvaccenic acid and formation of capsular polysaccharides. In addition, under acidic conditions $(\mathrm{pH}=4)$, the production of long-chain fatty acids in the cell membrane increases, resulting in a decrease in branching ratio [38]. This leads to a decrease in the hardness, elasticity and fluidity of the cell membrane. Other literature has shown that acetic acid can increase the surface area of the cell membrane, thereby reducing the relative area of passive diffusion of acetic acid into the cell [39], which increases biofilm composition and 
complements transcriptional regulation systems [40]. Under acetic acid conditions, the genes involved in cell membrane maturation will also change accordingly, such as luxS [41] gene and agr [42] gene.

In general, when acetic acid acts on Gram-positive bacteria, the cell membrane is stimulated by acetic acid. The cells begin to respond to the extracellular environment. Thus, cells adapt to adverse environments through mature cell membranes and begin to produce large amounts of bacteriocin to kill competitors or to signal to the population.

\section{Relationship between Induction of Bacteriocin Production and Metabolism of Acetic Acid}

\section{The Production Mechanism of Bacteriocin}

Bacteriocins are a class of antibacterial peptides or precursor peptides synthesized by bacteria. The synthesis of bacteriocin is strictly regulated, and it is generally synthesized and secreted in the logarithmic growth phase of bacteria and increases secretion as the number of bacteria increases. Next, the mechanism of bacteriocin production by Gram-positive bacteria was reviewed in terms of genomics and proteomics. At present, the research on the mechanism of bacteriocin production by Gram- positive bacteria is more mature for Streptococcus mutans and S. pneumoniae. There are two mechanisms for the production of bacteriocin, such as S. mutans (Fig. 1) [43]. The first is CSP (competence stimulating peptide) signaling that mediates bacteriocin expression. The $\operatorname{com} \mathrm{C}$ expresses a CSP signal peptide. The CSP signal peptide is cleaved and exported by the ComAB protein on the membrane [44]. After extracellular processing, mature CSP phosphorylates ComD. The phosphate group is then delivered to the ComE protein. Phosphorylated ComE protein activates the expression of the bacteriocin gene [43]. The second involves XIP (sigX-inducible peptide) signaling which induces bacteriocin synthesis. The comS gene expresses an XIP signal peptide which is secreted into the extracellular environment. The extracellular XIP peptide is then reintroduced by Opp permease. The XIP and ComR proteins interact directly to form a complex. This complex then induces transcription of $\operatorname{sig} X$ (sigma factor). SigX binds to RNA polymerase to activate the expression of the bacteriocin gene [45]. Simultaneously, SigX binds to the 5' end of the comE gene and induces comE transcription, increasing the ComE protein which is a phosphorylated substrate [43]. These indicate that bacteriocin is produced by two regulatory systems. A small amount of CSP can

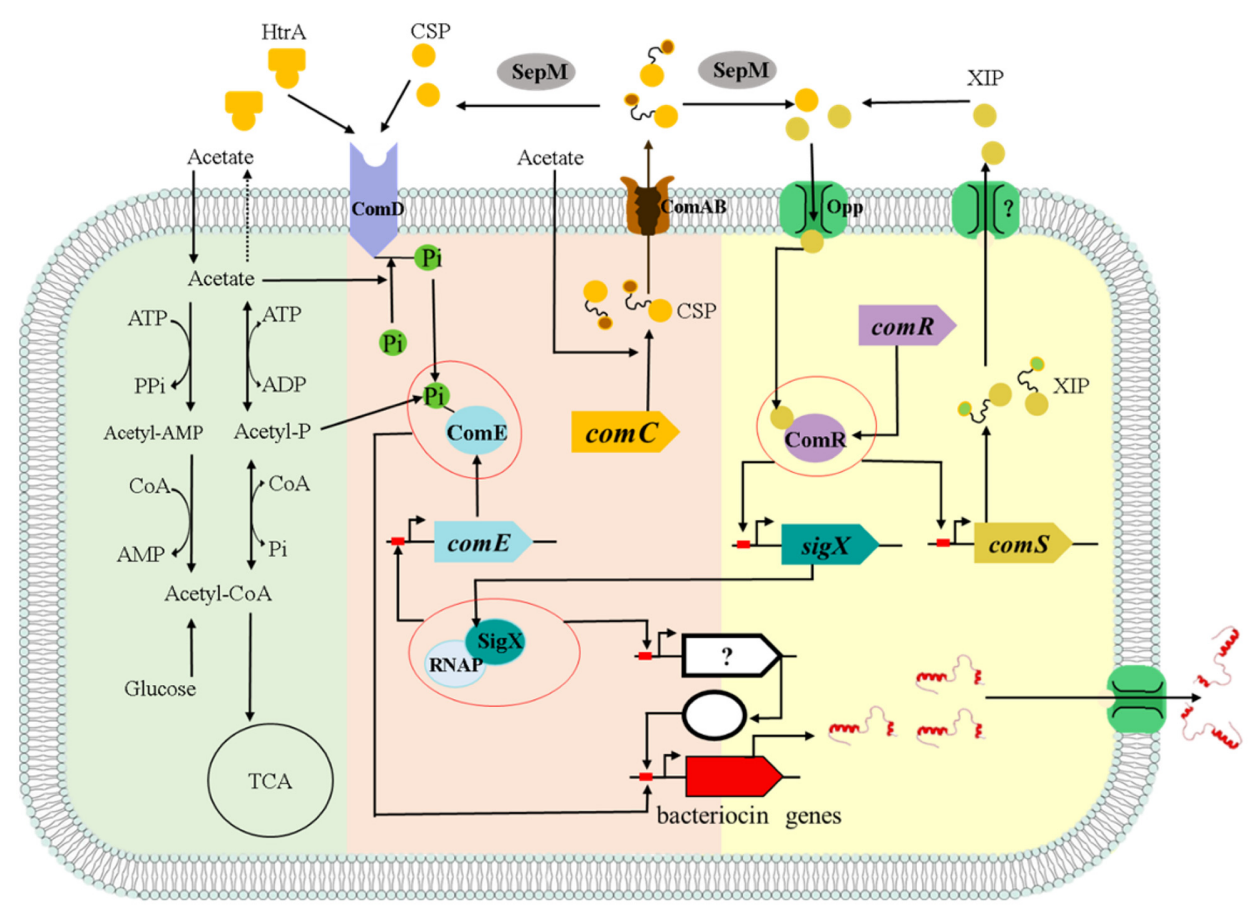

Fig. 1. The mechanism of production of Gram-positive bacteria bacteriocin and the effect of acetic acid on bacteriocin production. The green area represents acetic acid metabolism; the orange area represents the CSP regulatory system; the yellow area represents the XIP regulatory system. 
induce the appearance of a single peak of bacteriocin. A large number of CSPs can activate XIP signal induction, and the two signaling molecules together induce the appearance of bacteriocin double peaks.

\section{Both Acetic Acid and Bacteriocin Can Induce Bacteriocin Production}

A variety of environmental factors also affect the expression of bacteriocins, such as cell density, nutrient conditions, and acetic acid. The concentration of CSP signaling molecules is critical for the initial effects of bacteriocin production. HtrA serine protease digests CSP peptide pheromone extracellularly, controls the concentration of extracellular CSP, and normally the concentration of extracellular CSP is lower than the threshold concentration that induces bacteriocin production [46]. Another study indicates that HtrA controls the expression of bacteriocin by competing with CSP for the recognition site of the ComD protein in the two-component system [47]. The $\mathrm{pH}$ range of HtrA protein activity is between 5.5 and 10.0, so stimulation of acetic acid also attenuates HtrA activity [48]. Under acidic stress, CSP expression can be up-regulated [48]. A large number of CSPs are more likely to compete for recognition sites on ComD, attenuating HtrA inhibition [46]. A change in CSP concentration is a signal of whether a cell is stressed. At high concentrations of CSP, cells not only grow at a slower rate, but high concentrations of CSP can trigger cell autolysis [48]. Cell autolysis can slow down the degree of extracellular $\mathrm{pH}$ reduction and weaken competition for nutrients. Acetic acid and acetyl phosphate respectively phosphorylate the ComD protein and the ComE protein to promote bacteriocin expression $[49,50]$.

Both acetate and bacteriocin are dose-dependent inducers of bacteriocin production [19]. The biosynthesis of bacteriocin is dependent on the extracellular peptide produced by the strain, and bacteriocin can also act as an extracellular regulator of biosynthesis [51]. For example, Streptococcus CipB bacteriocin is a bifunctional peptide that combines lytic activity and transcriptional regulation [52]. Bacteriocin can be regulated in both species and populations. Optimal cell growth does not always result in a large production of bacteriocin. In general, low growth rates or adverse conditions may stimulate bacteriocin production [53].

\section{Effect of Acetic Acid on Bacteriocin-Related Plasmids}

Under acetic acid treatment, bacteria reduce catabolism, and the plasmid also undergoes a series of altered reactions [54]. Plasmid can regulate the expression of DNA-binding protein genes to achieve the survival and expression of extracellular DNA taken up by cells [55]. Acetic acid can damage DNA and inhibit new DNA synthesis, but it does not immediately cause leakage of intracellular components [56]. Furthermore, under acetic acid treatment, bacterial cells have high levels of purines and pyrimidines, which provides an advantageous environment for plasmidencoded gene expression [57]. Certain plasmids or DNA can self-transfer within a population to rapidly communicate and respond between bacteria [58]. This is in parallel with the actual conditions required for a large amount of bacteriocin to be produced. Some Gram-positive bacteria produce bacteriocins encoded by plasmids [59], such as the pXO1 plasmid of B. anthracis (encoding a putative membrane-bound bacteriocin) [60], and the pWcMBF8-1 plasmid of lactic acid bacteria (a component required for the synthesis of bacteriocin) [61]. Acetic acid at a concentration of $1.0 \%$ or higher increases the number of copies of the relevant plasmid, for example, the pGE1 plasmid and the pGE3 plasmid [57], which decompose acetic acid and the pJT2-1 plasmid, which enhance the resistance of acetic acid [62].

Due to their excellent antibacterial properties, bacteriocins have become the most promising alternative to antibiotics and have gradually attracted wider interest in the medical field. More and more scholars are beginning to pay attention to the study of bacteriocins. At present, Grampositive bacteria bacteriocin research mainly focuses on their transport proteins, bacteriostatic methods, and immune mechanisms. It is worth noting that there are unresolved problems with the bacteriocin production mechanism. For example, it is not known what transporter or system is used to secrete and treat XIP precursors (Fig. 1) [63], and there is no direct evidence that HtrA disrupts ComAB function or that HtrA blocks CSP-induced function [64]. There is a lack of research into the effects of acetic acid on quorum sensing in research progress. The metabolism of acetic acid, which affects bacterial life activities through material circulation and energy flow, is the core of central metabolism. Quorum sensing is a regulatory mechanism through which bacteria evolve under stress. Acetic acid metabolism and quorum sensing are a response of bacteria to environmental changes. But, how bacteria survive in unsuitable environments and how they maintain their population stability, i.e., bacterial physiology and group behavior, are important topics of ecology that require further study. 


\section{Acknowledgments}

This work was supported by the National Natural Science Foundation of China (31470537), Heilongjiang Provincial Key Laboratory of Plant Genetic Engineering and Biological Fermentation Engineering for Cold Region.

\section{Conflict of Interest}

The authors have no financial conflicts of interest to declare.

\section{References}

1. López-Cuellar MdR, Rodríguez-Hernández A-I, ChavarríaHernández N. 2016. LAB bacteriocin applications in the last decade. Biotechnol. Biotechnol. Equip. 30: 1039-1050.

2. Kaktcham PM, Temgoua JB, Ngoufack Zambou F, Diaz-Ruiz G, Wacher C, Perez-Chabela ML. 2017. Quantitative analyses of the bacterial microbiota of rearing environment, tilapia and common carp cultured in earthen ponds and inhibitory activity of its lactic acid bacteria on fish spoilage and pathogenic bacteria. World. J. Microbiol. Biotechnol. 33: 32.

3. Kumari S, Beatty CM, Browning DF, Busby SJ, Simel EJ, Hovel-Miner G, et al. 2000. Regulation of acetyl coenzyme A synthetase in Escherichia coli. J. Bacteriol. 182: 4173-4179.

4. Jia FF, Zheng HQ, Sun SR, Pang XH, Liang Y, Shang JC, et al. 2018. Role of luxs in stress tolerance and adhesion ability in Lactobacillus plantarum KLDS1.0391. Biomed. Res. Int. 2018: 4506829 .

5. Dobson A, Cotter PD, Ross RP, Hill C. 2012. Bacteriocin production: a probiotic trait? Appl. Environ. Microbiol. 78: 1-6.

6. Blanchard AE, Liao C, Lu T. 2016. An ecological understanding of quorum sensing-controlled bacteriocin synthesis. Cell. Mol. Bioeng. 9: 443-454.

7. Maldonado-Barragan A, Caballero-Guerrero B, LucenaPadros H, Ruiz-Barba JL. 2013. Induction of bacteriocin production by coculture is widespread among plantaricinproducing Lactobacillus plantarum strains with different regulatory operons. Food Microbiol. 33: 40-47.

8. Ge J, Fang B, Wang Y, Song G, Ping W. 2014. Bacillus subtilis enhances production of Paracin1. 7, a bacteriocin produced by Lactobacillus paracasei HD1-7, isolated from Chinese fermented cabbage. Ann. Microbiol. 64: 1735-1743.

9. Moreno-Gamez S, Sorg RA, Domenech A, Kjos M, Weissing FJ, van Doorn GS, et al. 2017. Quorum sensing integrates environmental cues, cell density and cell history to control bacterial competence. Nat. Commun. 8: 854.

10. Talagrand-Reboul E, Jumas-Bilak E, Lamy B. 2017. The social life of Aeromonas through biofilm and quorum sensing systems. Front. Microbiol. 8: 37.
11. Paczkowski JE, Mukherjee S, McCready AR, Cong JP, Aquino CJ, Kim $\mathrm{H}$, et al. 2017. Flavonoids suppress Pseudomonas aeruginosa virulence through allosteric inhibition of quorum-sensing receptors. J. Biol. Chem. 292: 4064-4076.

12. Johnson EM, Jung DY, Jin DY, Jayabalan DR, Yang DSH, Suh JW. 2018. Bacteriocins as food preservatives: challenges and emerging horizons. Crit. Rev. Food. Sci. 58: 2743-2767.

13. Abbasiliasi S, Ramanan RN, Ibrahim TAT, Mustafa S, Mohamad R, Daud HHM, et al. 2014. Effect of medium composition and culture condition on the production of bacteriocin-like inhibitory substances (BLIS) by Lactobacillus paracaseiLA07, a strain isolated from Budu. Biotechnol. Biotechnol. Equip. 25: 2652-2657.

14. De Kwaadsteniet M, Todorov SD, Knoetze H, Dicks LM. 2005. Characterization of a $3944 \mathrm{Da}$ bacteriocin, produced by Enterococcus mundtii ST15, with activity against Grampositive and Gram-negative bacteria. Int. J. Food Microbiol. 105: 433-444.

15. Yang E, Fan L, Yan J, Jiang Y, Doucette C, Fillmore S, et al. 2018. Influence of culture media, $\mathrm{pH}$ and temperature on growth and bacteriocin production of bacteriocinogenic lactic acid bacteria. AMB. Express. 8: 10.

16. Agaliya PJ, Jeevaratnam K. 2013. Characterisation of the bacteriocins produced by two probiotic Lactobacillus isolates from idli batter. Ann. Microbiol. 63: 1525-1535.

17. Embaby AM, Heshmat Y, Hussein A, Marey HS. 2014. A sequential statistical approach towards an optimized production of a broad spectrum bacteriocin substance from a soil bacterium Bacillus sp. YAS 1 strain. ScientificWorldJournal 2014: 1-16.

18. Lozo J, Vukasinovic M, Strahinic I, Topisirovic L. 2004. Characterization and antimicrobial activity of bacteriocin 217 produced by natural isolate Lactobacillus paracasei subsp. paracasei BGBUK2-16. J. Food Prot. 67: 2727-2734.

19. Nilsson L, Nielsen MK, Ng Y, Gram L. 2002. Role of acetate in production of an autoinducible class iia bacteriocin in Carnobacterium piscicola A9b. Appl. Environ. Microbiol. 68: 2251-2260.

20. Cabo ML, Braber AF, Koenraad PM. 2002. Apparent antifungal activity of several lactic acid bacteria against Penicillium discolor is due to acetic acid in the medium. J. Food Prot. 65: 1309-1316.

21. Casal M, Paiva S, Queiros O, Soares-Silva I. 2008. Transport of carboxylic acids in yeasts. FEMS Microbiol. Rev. 32: 974-994.

22. Mols M, Abee T. 2008. Role of ureolytic activity in Bacillus cereus nitrogen metabolism and acid survival. Appl. Environ. Microbiol. 74: 2370-2378.

23. Hosein AM, Breidt F, Jr., Smith CE. 2011. Modeling the effects of sodium chloride, acetic acid, and intracellular $\mathrm{pH}$ on survival of Escherichia coli O157:H7. Appl. Environ. Microbiol. 77: 889-895. 
24. Xiao KK, Guo CH, Zhou Y, Maspolim Y, Wang JY, Ng WJ. 2013. Acetic acid inhibition on methanogens in a two-phase anaerobic process. Biochem. Eng. J. 75: 1-7.

25. Lund P, Tramonti A, De Biase D. 2014. Coping with low pH: molecular strategies in neutralophilic bacteria. FEMS Microbiol. Rev. 38: 1091-1125.

26. Woo JM, Kim JW, Song JW, Blank LM, Park JB. 2016. Activation of the glutamic acid-dependent acid resistance system in Escherichia coli BL21(DE3) leads to increase of the fatty acid biotransformation activity. PLoS One 11: e0163265.

27. Gao C, Zheng Y. 2018. Control of acetic acid metabolism of recombinant Yarrowia lipolytica for efficient succinic acid production. Chin. J. Biotechnol. 34: 389-395.

28. Adachi K, Ohtani K, Kawano M, Singh RP, Yousuf B, Sonomoto K, et al. 2018. Metabolic dependent and independent $\mathrm{pH}$-drop shuts down VirSR quorum sensing in Clostridium perfringens. J. Biosci. Bioeng. 125: 525-531.

29. Fernandez I, Sycz G, Goldbaum FA, Carrica MDC. 2018. Acidic $\mathrm{pH}$ triggers the phosphorylation of the response regulator NtrX in alphaproteobacteria. PLoS One 13: e0194486.

30. Wang J, Hao C, Huang H, Tang W, Zhang J, Wang C. 2018. Acetic acid production by the newly isolated Pseudomonas sp. CSJ-3. Braz. J. Chem. Eng. 35: 1-9.

31. Peeters SH, de Jonge MI. 2018. For the greater good: Programmed cell death in bacterial communities. Microbiol. Res. 207: 161-169.

32. Ding J, Holzwarth G, Penner MH, Patton-Vogt J, Bakalinsky AT. 2015. Overexpression of acetyl-CoA synthetase in Saccharomyces cerevisiae increases acetic acid tolerance. FEMS. Microbiol. Lett. 362: 1-7.

33. Lyon GJ, Novick RP. 2004. Peptide signaling in Staphylococcus aureus and other Gram-positive bacteria. Peptides 25: 13891403.

34. Mhatre E, Monterrosa RG, Kovacs AT. 2014. From environmental signals to regulators: modulation of biofilm development in Gram-positive bacteria. J. Basic. Microbiol. 54: 616-632.

35. Mols M, Abee T. 2011. Bacillus cereus responses to acid stress. Environ. Microbiol. 13: 2835-2843.

36. Stanley NR, Lazazzera BA. 2004. Environmental signals and regulatory pathways that influence biofilm formation. Mol. Microbiol. 52: 917-924.

37. Trcek J, Mira NP, Jarboe LR. 2015. Adaptation and tolerance of bacteria against acetic acid. Appl. Microbiol. Biotechnol. 99: 6215-6229.

38. Wu X, Zhang L, Jin X, Fang Y, Zhang K, Qi L, et al. 2016. Deletion of JJ1 improves acetic acid tolerance and bioethanol fermentation performance of Saccharomyces cerevisiae strains. Biotechnol. Lett. 38: 1097-1106.

39. Trcek J, Jernejc K, Matsushita K. 2007. The highly tolerant acetic acid bacterium Gluconacetobacter europaeus adapts to the presence of acetic acid by changes in lipid composition, morphological properties and PQQ-dependent ADH expression. Extremophiles 11: 627-635.

40. Tallawi M, Opitz M, Lieleg O. 2017. Modulation of the mechanical properties of bacterial biofilms in response to environmental challenges. Biomater. Sci. 5: 887-900.

41. Liu L, Wu R, Zhang J, Shang N, Li P. 2017. D-Ribose interferes with quorum sensing to inhibit biofilm formation of Lactobacillus paraplantarum L-ZS9. Front. Microbiol. 8: 1860.

42. Novick RP, Geisinger E. 2008. Quorum sensing in Staphylococci. Annu. Rev. Genet. 42: 541-564.

43. Reck M, Tomasch J, Wagner-Dobler I. 2015. The alternative sigma factor SigX controls bacteriocin synthesis and competence, the two quorum sensing regulated traits in Streptococcus mutans. PLoS Genet. 11: e1005353.

44. Li YH, Lau PC, Lee JH, Ellen RP, Cvitkovitch DG. 2001. Natural genetic transformation of Streptococcus mutans growing in biofilms. J. Bacteriol. 183: 897-908.

45. Mashburn-Warren L, Morrison DA, Federle MJ. 2010. A novel double-tryptophan peptide pheromone controls competence in Streptococcus spp. via an Rgg regulator. Mol. Microbiol. 78: 589-606.

46. Cassone M, Gagne AL, Spruce LA, Seeholzer SH, Sebert ME. 2012. The HtrA protease from Streptococcus pneumoniae digests both denatured proteins and the competencestimulating peptide. J. Biol. Chem. 287: 38449-38459.

47. Sebert ME, Patel KP, Plotnick M, Weiser JN. 2005. Pneumococcal HtrA protease mediates inhibition of competence by the CiaRH two-component signaling system. J. Bacteriol. 187: 3969-3979.

48. Perry JA, Jones MB, Peterson SN, Cvitkovitch DG, Levesque CM. 2009. Peptide alarmone signalling triggers an autoactive bacteriocin necessary for genetic competence. Mol. Microbiol. 72: 905-917.

49. Monedero V, Revilla-Guarinos A, Zuniga M. 2017. Physiological role of two-component signal transduction systems in food-associated lactic acid bacteria. Adv. Appl. Microbiol. 99: 1-51.

50. Alcantara C, Bauerl C, Revilla-Guarinos A, Perez-Martinez G, Monedero V, Zuniga M. 2016. Peptide and amino acid metabolism is controlled by an OmpR-family response regulator in Lactobacillus casei. Mol. Microbiol. 100: 25-41.

51. Yi H, Han X, Yang Y, Liu W, Liu H, Zhang Y, et al. 2013. Effect of exogenous factors on bacteriocin production from Lactobacillus paracasei J23 by using a resting cell system. Int. J. Mol. Sci. 14: 24355-24365.

52. Dufour D, Cordova M, Cvitkovitch DG, Levesque CM. 2011. Regulation of the competence pathway as a novel role associated with a streptococcal bacteriocin. J. Bacteriol. 193: 6552-6559.

53. Md Sidek NL, Halim M, Tan JS, Abbasiliasi S, Mustafa S, Ariff AB. 2018. Stability of bacteriocin-like inhibitory substance (BLIS) produced by Pediococcus acidilactici kp10 at different extreme conditions. Biomed Res. Int. 2018: 5973484. 
54. Buch AD, Archana G, Naresh Kumar G. 2010. Broad-hostrange plasmid-mediated metabolic perturbations in Pseudomonas fluorescens 13525. Appl. Microbiol. Biotechnol. 88: 209-218.

55. Wang B, Zhang H, Liang D, Hao P, Li Y, Qiao J. 2017. Acid or erythromycin stress significantly improves transformation efficiency through regulating expression of DNA binding proteins in Lactococcus lactis F44. J. Dairy. Sci. 100: 9532-9538.

56. Tan SM, Lee SM, Dykes GA. 2015. Acetic acid induces pHindependent cellular energy depletion in Salmonella enterica. J. Dairy. Sci. 12: 183-189.

57. Akasaka N, Astuti W, Ishii Y, Hidese R, Sakoda H, Fujiwara S. 2015. Change in the plasmid copy number in acetic acid bacteria in response to growth phase and acetic acid concentration. J. Biosci. Bioeng. 119: 661-668.

58. Berger M, Berger P, Denamur E, Mellmann A, Dobrindt U. 2018. Core elements of the vegetative replication control of the Inc1 plasmid pO104_90 of Escherichia coli O104:H4 also regulate its transfer frequency. Int. J. Med. Microbiol. 308: 962-968.

59. Miljkovic M, Lozo J, Mirkovic N, O'Connor PM, Malesevic M, Jovcic B, et al. 2018. Functional characterization of the
Lactolisterin BU gene cluster of Lactococcus lactis subsp. lactis BGBU1-4. Front. Microbiol. 9: 2774.

60. Perlinska A, Grynberg M. 2014. Bacillus anthracis pXO1 plasmid encodes a putative membrane-bound bacteriocin PeerJ 2: e679.

61. Malik A, Sumayyah S, Yeh CW, Heng NC. 2016. Identification and sequence analysis of pWcMBF8-1, a bacteriocin-encoding plasmid from the lactic acid bacterium Weissella confusa. FEMS Microbiol. Lett. 363 pii: fnw059.

62. Trček J. 2014. Plasmid analysis of high acetic acid-resistant bacterial strains by two-dimensional agarose gel electrophoresis and insights into the phenotype of plasmid pJK2-1. Ann. Microbiol. 65: 1287-1292.

63. Khan R, Rukke HV, Ricomini Filho AP, Fimland G, Arntzen MO, Thiede B, et al. 2012. Extracellular identification of a processed type II ComR/ComS pheromone of Streptococcus mutans. J. Bacteriol. 194: 3781-3788.

64. Kochan TJ, Dawid S. 2013. The HtrA protease of Streptococcus pneumoniae controls density-dependent stimulation of the bacteriocin blp locus via disruption of pheromone secretion. J. Bacteriol. 195: 1561-1572. 